Participative Journal

Jurnal Pengabdian Pada Masyarakat

Vol. 01, No. 01, April 2021

Homepage journal: https://jurnal.jurmat.com/index.php/pj

\title{
KONSTRIBUSI KKP UIN MATARAM DALAM MENINGKATKAN KESADARAN MASYARAKAT KEMBANG KERANG MEMATUHI PROTOCOL COVID-19
}

\author{
Al Kusaeri*1 \\ ${ }^{*}$ Affiliasi: Universitas Islam Negeri Mataram
}

\begin{abstract}
Since the enactment of the COVID-19 pandemic status by the World Health Organization (WHO) on March 11, 2020. Massive joint efforts are needed by the world community to fight the spread of the COVID 19 virus so as not to cause more victims. The crisis due to the spread of Covid 19 is not only seen as a health crisis, but affects crises in various sectors of public life, because the impact affects all sectors of life. Facing this, in addition to medical efforts by finding anti-viruses, public awareness of a healthy lifestyle is also needed, namely getting used to behavior following health protocols in carrying out various life activities to inhibit and stop the rate of transmission of Covid 19. Paying attention to the movement of the spread of Covid 19 which runs very fast Therefore, fast public awareness is also needed to get used to following the covid 19 protocol. For this reason, all levels of society must take part in increasing public awareness to carry out various activities by following the Covid 19 protocol including Higher Education, as the efforts that have been carried out by UIN Mataram through Participatory Work Lecture (KKP) activities in 2020.
\end{abstract}

Keywords: KKP UIN Mataram, Public Awareness, Covid Protocol 19

Journal Info:

Received, 20 Februari 2021 | Revised, 20 Maret 2021 | Published, 12 April 2021

\footnotetext{
${ }^{1}$ Corresponden to the author: Prodi Tadris Matematika, UIN Mataram.

Jl. Gajah Mada Jempong, Indonesia (83116), email address : alkusaeri@uinmataram.ac.id
} 


\begin{abstract}
Abstrak
Sejak diberlakukannya status pandemic covid 19 oleh badan kesehatan dunia (WHO) pada tanggal 11 maret 2020. Diperlukan usaha bersama yang masif oleh masyarakat dunia untuk melawan penyebaran virus COVID 19 agar tidak menimbulkan korban yang lebih banyak. Krisis akibat penyebaran covid 19 tidak hanya dipandang sebagai krisis kesehatan semata, akan tetapi mempengaruhi krisis diberbagai sektor kehidupan masyarakat, karena pengaruh yang ditimbulkan menyentuh kepada seluruh sektor kehidupan. Menghadapi hal tersebut, selain upaya medis dengan menemukan anti virusnya, diperlukan juga kesadaran masyarakat akan pola hidup sehat, yaitu membiasakan prilaku mengikuti protocol kesahatan dalam melaksanakan berbagai aktivitas kehidupan guna menghambat dan memberhentikan laju penularan covid 19. Memperhatikan pergerakan penyebaran covid 19 yang berjalan sangat cepat, maka diperlukan kesadaran masyarakat yang cepat pula untuk membiasakan diri mengikuti protocol covid 19. Untuk itu, seluruh lapisan masyarakat harus mengambil bagaian dalam meningkatkan kesadaran masayarakat melaksankan berbagai aktivitas dengan mengikuti protocol covid 19 termasuk Perguruan Tinggi, sebagimana usaha yang sudah dilakukan oleh UIN Mataram melalui kegiatan Kuliah Kerja Partisipatif (KKP) pada tahun 2020.
\end{abstract}

Kata Kunci: KKP UIN Mataram, Kesadaran Masyarakat, Protocol Covid 19

\title{
Pendahuluan
}

Kegiatan Pengabdian kepada masyarakat merupakan salah satu dari tri dharma Perguruan Tinggi yang harus dilaksanakan oleh civitas akademik (dosen dan mahasiswa). Akibat dari pentingnya kegiatan pengabdian dilaksanakan oleh mahasiswa, setiap Perguruan Tinggi menyusun kurikulum pendidikan dengan menetapkan kegiatan pengabdian sebagai salah satu Mata Kuliah wajib yang harus ditempuh oleh setiap mahasiswa untuk mendapatkan gelar sarjana. Hal tersebut merupakan implementasi dari fungsi dan tujuan penyelenggaraan Pendidikan Tinggi sebagaimana yang tercantum pada pasal 4 dan 5 UU Republik Indonesia Nomor 12 Tahun 2012 tentang Pendidikan Tinggi, bahwa: perguruan tinggi berfungsi mengembangkan kemampuan dan membentuk watak serta peradaban bangsa yang bermartabat dalam rangka mencerdaskan kehidupan bangsa dengan tujuan terwujudnya Pengabdian kepada Masyarakat berbasis penalaran dan karya Penelitian yang bermanfaat dalam memajukan kesejahteraan umum dan mencerdaskan kehidupan bangsa.

Masyarakat cerdas dapat dimaknai sebagai masayarakat yang mampu bertahan dan mencari solusi dalam setiap masalah yang terjadi dalam kehidupan bermasyarakat. Masyarakat yang menyadari akan potensi dan bagaimana menyikapi setiap persoalan atau fenomena yang terjadi di tengah-tengah masyarakat. Dikarenakan tidak ada satu masyarakatpun yang tidak terjadi di dalamnya berbagai maslah. Setiap masalah yang terjadi dalam kehidupan social tentu tidaklah mudah untuk dicarikan solusinya, karena hal tersebut terkait dengan kehidupan orang banyak, sebagaimana definisi dari masalah social sendiri adalah any condition that is harmful to society; 
but the matter is not so Simple, for the meanings of such everyday terms as harm and Society are far from clear (Clifton \& Dennis, 2006) bermakna bahwa seluruh komponen (termasuk perguruan tinggi) dalam kehidupan bermasyarakat harus terlibat secara aktif dalam mencari solusi atas masalah social yang terjadi, sebab masalah sosial bukanlah masalah yang sederhana dan memiliki pengaruh yang sangat beresiko terhadap kehidupan masayarakat.

Saat ini, seluruh masyarakat dunia sedang dihadapkan dengan satu masalah yang sangat komplek, yaitu menyebarnya virus Covid 19 yang mengganggu kesehatan setiap manusia bahkan akibatnya dapat berupa kematian. Meluasnya penyebaran covid 19 keseluruh dunia membuat badan kesehatan dunia WHO pada tanggal 11 maret 2020 menetapkan covid 19 sebagai pandemic. Covid 19 dikategorikan sebagai penyakit yang penyebarannya sudah menjangkau seluruh dunia dengan cepat. Menjadi masalah social yang komplek, karena akibat dari menyebarnya covid 19 masalah yang terjadi tidak hanya pada masalah kesehatan, akan tetapi mencakup seluruh aspek kehidupan masayarakat seperti ekonomi, pendidikan, social budaya, dan bahkan kehidupan dalam beragama. Di samping itu juga usaha-usaha yang sudah dilakukan untuk menyelesaiakn masalah tersebut belum dapat dikatakan sebagai solusi yang final, seperti ditemukannya vaksin. Samapi saat ini, selurh lapisan masayarakat masih tetap diminta untuk untuk mematuhi protocol kesehatan, yang meskipun berat, akan tetapi harus dapat dibiasakan, agar kesadaran akan protocol kesehatan guna menghindari dampak dari penyebaran covid 19 dapat menjadi kebiasaan dalam kehidupan sehari-hari.

Agar protocol kesehatan selalu di taati dan bahkan menjadi kebiasaan setiap anggota masyarakat, maka penting dibangun kesadaran akan pentingnya kesehatan pada diri setiap anggota masyarakat. Untuk itu, Perguruan tinggi di Indonesia termasuk UIN Mataram melaksanakan kegiatan pengabdian masyarakat melalui kegiatan KKP pada tahun 2020, salah satunya bertujuan untuk membantu pemerintah mensosialisasikan dan mengajak anggota masyarakat menyadari pentingnya mentaati protocol kesehatan covid 19, sebagai bagian dari tanggungjawab social perguruan tinggi dalam membantu masyarakat keluar dari masalah yang dihadapinya. Membangun kesadaran diri setiap anggota masyarakat merupakan kunci utama agar protocol kesehatan pada akhirnya dapat menjadi kebiasaan hidup, sebab kesadaran diri yang dimiliki oleh setiap orang akan membuat sesorang menyadari akan setiap tindakan yang dilakukannya (Mead,1999), sesorang dapat memahami diri dan kondisinya dengan tepat (achmanto mendatu, 2020). Menurut Dessler (1997); Mathis dan Jackson (2021) menyatakan kebermaknaan seseorang atau sumber daya manusia dalam kehidupan berorganisasi atau berkelompok tergantung pada kesadaran dirinya memahami tujuan bersama. Pentingnya kesadaran masyarakat kaitannya dengan dampak dari pandemic covid 19 yang merupakan bencana kesehatan bagi masayarakat dunia, karena menurut Carter (1992) menyatakan bahwa masyarakat merupakan tokoh utama dan memegang peran penting dalam mengurangi resiko bencana (mitigasi).

Atosokhi Gea (2002) mendefinisikan kesadaran diri sebagai sebuah penguasaan atas gambaran dan jati diri, dengan demikian seseorang akan dengan sadar melakukan sesuatu atas dasar pengetahuan akan kemampuan dirinya. kesadaran diri (selfawareness) merupakan perhatian yang terus menerus terhadap keadaan batin individu. Berdasarkan hal ini, kesadaran diri (self awareness) merupakan salah satu komponen dari kecerdasan emosional. Secara konseptual, 
faktor-faktor yang mempengaruhi terhadap tumbuh dan berkembangnya kesadaran dapat didekati dengan beragam pendekatan disiplin ilmu. Mandatu (2010) menyatakan bahwa kasadaran diri addalah kondisi dimana seseorang kritis terhadap informasi akan dirinya. Kesadaran diri merupakan satu pengetahuan dimana seserorang mengetahui apa yang dilakukan dan mengapa hal tersebut dilakukan. Membangun kesadaran masyarakat adalah upaya untuk menyadari diri setiap anggota masyarakat agar memahami akan apa yang semestinya dilakukan. Kaitannya dengan usaha meningkatkan kesadaran masyarakat untuk menerapkan protocol covid 19. UIN Mataram melalui kegiatan KKP-DR yang dilakukan oleh mahasiswa pada tahun 2020, berupaya ikut andil dalam membangun kesadaran diri masyarakat untuk menerapkan protocol covid 19, dengan tujuan agar setiap anggota masyarakat menyadari bahaya covid 19 terhadap dirinya dan mengetahui apa yang harus dilakukan untuk menghindari dirinya dari dampak bahaya covid 19. Artikel ini mendeskripsikan tentang konstribusi UIN Mataram dalam meningkatkan kesadaran masyarakat untuk menerapkan protocol covid 19.

\section{Metode}

Kuliah Kerja Partisipatif UIN Mataram secara umum dilaksanakan berbasis desa setempat, bermakna bahwa mahasiswa melaksanakan KKP di desa masing-masing yang diistilahkan dengan Kuliah Kerja Partisipatif-Dari Rumah (KKP-DR), dengan pertimbangan kondisi pembatasan interaksi dan agar menjamin keberterimaan masyarakat atas program yang akan dilaksanakan oleh peserta KKP-DR. Untuk mencapai tujuan pelaksanaan KKP-DR berkaitan dengan kesadaran masyarakat mematuhi protocol covid 19 di Desa Kembang Kerang Kecamatan Aikmel Lombok Timur NTB. Mahasiswa UIN Mataram Melaksanakan seluruh programnya dengan metode: 1) Partisipatif action, yaitu kegiatan yang dilakukan dalam bentuk aksi nyata dimana peserta KKP-DR secara langsung melaksanakan programnya sendiri; 2) Informatif action, yaitu kegiatan phublikasi informasi untuk memberikan informasi kepada anggota masyarakat yang tidak dapat ditemuai secara langsung; dan 3) Practical Action, yaitu kegiatan langsung guna mempraktekkan protocol kesehatan kepada anggota masyarakat.

\section{Hasil dan Pembahasan}

Kegiatan Kuliah Kerja Partisipatif (KKP) merupakan kegiatan pengabdian kepada masyarakat

yang rutin dilakukan mahasiswa semester 7 UIN Mataram. Pada tahun 2020 mahasiswa melaksanaan KKP dalam situasi yang berbeda. Menyikapi adanya pandemic Covid-19 mahasiswa UIN Mataram melaksanakan Kegiatan KKP dari rumah masing-masing, atau disebut dengan KKPDR (Kuliah Kerja Partisipatif Dari Rumah). Sejak awal tahun 2020, Indonesia secara khusus dan dunia mengalami pandemic global yaitu munculnya virus Covid-19 yang memicu munculnya permaslahan serius diberbagai belahan dunia termasuk Indonesia. Berbagai kebijakan sudah diambil oleh pemerintah untuk menanggulangi dampak dari pandemic covid 19. Salah satunya adalah dengan melibatkan berbagai pihak untuk membantu penanganan dan pencegahannnya, salah satunya adalah keterlibatan dan keikutsertaan perguruan tinggi. Perguruan Tinggi melalui kebijakan akademis dituntut dapat berperan aktif dalam membantu msayarakat dan pemerintah serta menjadi solution maker terhadap permasalahan yang sedang dihadapi. 
Tujuan dilaksnakannya KKP-DR 2020 di UIN Mataram adalah sebagai salah satu usaha untuk menyebarluaskan ilmu pengetahuan, teknologi, dan seni kepada masyarakat. Kegiatan tersebut harus mampu memberikan suatu nilai tambah bagi masyarakat, baik dalam kegiatan ekonomi, kebijakan, dan perubahan perilaku (sosial). Kegiatan pengabdian harus mampu memberi perubahan bagi individu/masyarakat maupun institusi baik jangka pendek maupun jangka panjang. Pelaksanaan KKP-DR dilaksanakan oleh mahasiswa melalui berbagai program pilihan sesuai dengan keadan dan kebutuhan di lokasi KKP dengan pemanfaatan IPTEK secara online. Diantara program-program pilihan tersebut adalah edukasi masyarakat, relawan pencegahan Covid-19 secara langsung dilingkungan masyarakat dan puskesmas serta posko penanganan terdekat dengan tempat tinggal, kampanye kesehatan dan pencegahan melalui platform media sosial seperti instagram, facebook, twitter, whatsapp, youtube serta platform-platfor popular lainnya dalam bentuk video, foto, poster, serta karya tulis dalam bentuk buku. Usaha tersebut dilakukan sebagai bentuk konstribusi UIN Mataram dalam mengupayakan munculnya kesadaran masyarakat dalam mentaati protokol kesehatan akibat dari covid 19, karena dengan pelaksanakan KKP DR yang dilaksanakan pada tanggal 2 Juli - 15 Agustus 2020, tentu tidak banyak yang dapat dilakukan untuk mengurangi laju penularan covid 19, namun cukup untuk memperkenalkan kepada masyarakat akan pentingnya kesadaran mentaati protocol kesehatan yang sudah ditetapkan oleh pemerintah.

Mengikuti pola kegiatan KKP-DR 2020, pelaksanaan KKP tersebar di seluruh wilayah asala mahasiswa UIN Mataram, yaitu NTB, NTT, dan Bali, serta beberapa daerah lainnya meski hanya 1 mahasiswa, termasuk pelaksanaan KKP-DR di desa Kembang Kerang Kecamatan Aikmel Kabupaten Lombok Timur NTB. Kelompok yang melaksanakan kegiatan KKP di lokasi tersebut adalah anggota kelompok 22, dimana 4 diantara anggotanya berasala dari desa tersebut. Beberapa kegiatan yang dilakukan pada saat KKP kaitannya dengan meningkatkan kesadaran masyarakat akan pentingnya mentaati protocol kesehatan covid 19 adalah sebagai berikut:

\section{Edukasi Protokol Kesehatan}

Covid 19 dinyatakan sebagai virus baru yang dideteksi pertama di Wuhan Cina. Ganasnya virus tersebut, sehingga memeiliki efek dan laju penyebaran yang cukup tinggi. Dalam beberapa bulan virus tersebut sudah menyebar di seluruh duni, virus ini menyerang system pernafasan manusia yang memunculkan gejala demam, sesak nafas, dan efek lain tergantung rekam riawayat kesehatan orang yang terdampak. Karena virus tersebut dikategorikan baru dan penyebarannya sangat cepat, langkah pertama yang di lakukan dan diterapkan oleh seluruh Negara yaitu menerapkan protocol kesehatan yang di kenal dengan 3M (Mencuci Tangan, Menggunakan

\section{Masker, dan Menjaga Jarak).}

Langkah tersebut merupakan upaya tercepat yang dapat dilakukan, meskipun tidak cepat direspon dan di taati oleh seluruh lapisan bermasyarakat. Dikarenakan pola hidup yang diterapkan sebelum covid 19 sudah membawa rasa nyaman dalam bergaul ditengah-tengah masyarakat. Seiring dengan meningkatnya angka orang yang terdampak atau terpapar virus covid 19, kesadaran masyarakat mulai meningkat untuk menerapkan protocol kesehatan dalam kehidupan 
sehari-hari meskipun tidak rutin diterakan. Perbedaan tingkat pemahaman dan kedisiplinan menjadi factor yang mempengaruhi kesadaran masyarakat dalam mentaati protocol kesehatan.
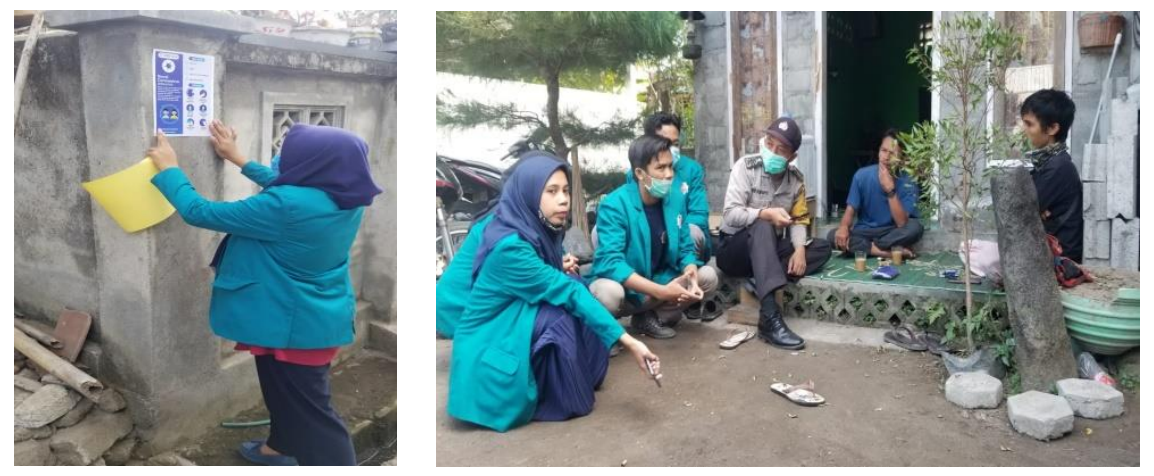

Gambar 1. Pemasangan Pamplet dan home visit Sosialisasi Protokol Kesehatan

Memperhatikan kondisi tersebut, mahasiswa KKP-DR UIN Mataram melakukan upaya untuk mengedukasi anggota masyarakat tentang bagaimana menerapkan protocol kesehatan, sebab kesadaran akan pentingnya mengikuti protocol kesehatan yang masih rendah, juga dipengaruhi oleh kekuarngtahuan anggota masyarakat tentang keberadaan virus covid 19, dampaknya terhadap kesehatan, dan termasuk bagaimana pelaksanaan protocol kesehatan. Selama KKP DR dilaksankan, mahasiswa UIN Mataram melakukan edukasi tentang seperti apa dan bagiamana protocol kesehatan dilakukan atau diterapkan. Edukasi dilakukan dengan dua cara, yaitu pendekatan langsung kepada masyarakat dan penyebaran pamphlet informasi.

Pendekatan langsung kepada masyarakat dilakukan dengan mendatangi setiap anggota masyarakat kerumahnya masing-masing, kegiatan tersebut dilakukan dengan melibatkan aparat keamanan yaitu polisi. Hal tersebut dilakukan agar kehadiran mereka dapat langsung diterima, dilibatkannya aparat kemanan untuk mengedukasi masyarakat tentang penerapan protocol kesehatan karena secara nasional kepolisian juga merupakan salah satu unsur yang termasuk dalam Satgas Penanggulanagn Covid-19. Sementara, cara yang kedua dalam mengedukasi masyarakat tentang pentingnya penerapan protocol kesehatan adalah dengan menempel pamplet informasi di setiap sudut desa, pemasangan pamphlet dilakukan setelah diizinkan oleh pihak pemerintah desa atau dusun. Melalui pamplet ini, anggota masyarakat yang tidak dapat ditemui di rumahnya karena pergi ke sawah, pasar, dan tempat bekerja lainnya tetap dapat memperoleh informasi, sambil berjalan di tengah dusunnya mereka dapat membaca informasi yang terdapat di pamphlet tersebut, sehingga semua anggota masyarakat di kembang kerang mendapatkan informasi yang benar tentang seperti apa dan bagaimana protocol kesehatan covid 19 diterapkan.

\section{Bina Lingkungan}

Covid 19 yang berasal dari Cina, menurut informasi muncul akibat lingkungan yang kurang bersih, berdasarkan berita di awal-awal terdeteksinya virus ini, disinyalir merupakan akibat dari kondisi pasar penjualan berbagai jenis daging yang dilakukan dengan kurang higeinis. Selain itu, melihat efek yang ditimbulkan pada orang yang sudah terpapar covid yaitu terjadinya 
permasalahan di saluran pernapasan, maka penting dilakukannya kegiatan bina lingkungan yaitu kegiatan yang membuat kondisi lingkungan menjadi bersih. Lingkungan yang bersih akan mengurangi munculnya bibit penyakit yang akan membuat daya tahan tubuh kita melemah. Virus covid 19 akan lebih cepat bereaksi apabila terkena pada seseorang yang kondisi imun tubuhnya sedang menurun.
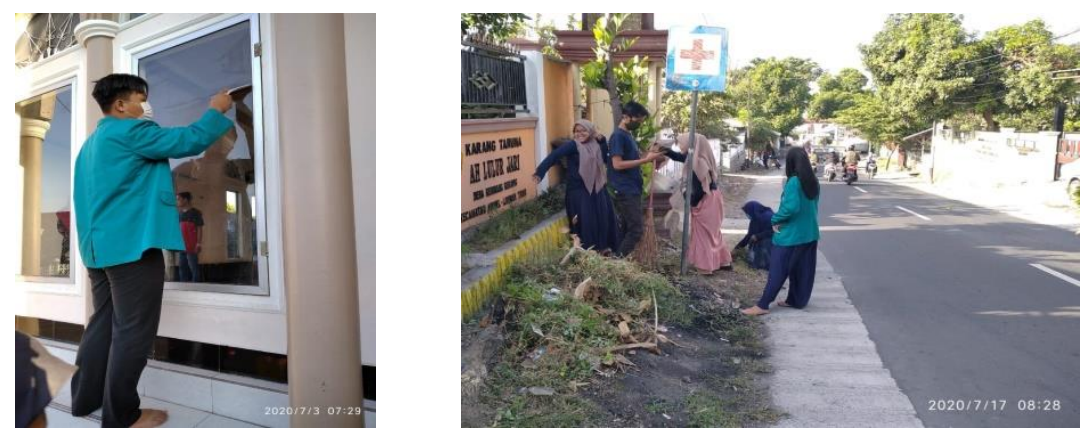

Gambar 2. Kegiatan Kebersihan Lingkungan

Kegiatan bina lingkungan yang dilakukan oleh peserta KKP-DR UIN Mataram adalah melakukan kegiatan bersih-bersih di lingkungan, perkantoran, dan tempat layanan umum bagi masyarakat. Hal tersebut dilakukan karena meskipun ada pembatasan interaksi, masyarakat tidak bias lepas sama sekali untuk tidak mengunjungi tempat-tempat layanan tersebut datau melkukan aktivitas lain disekitar lingkungan masyarakatnya. Kegiatan menjaga kebersihan lingkungan dilakukan untuk memunculkan kesadaran bagi anggota masyarakat agar selalu menjaga kebersihan dilingkungan tempat tinggalnya, minimal menjaga kebersihan lingkungan disekitar rumahnya.

Menindaklanjuti kegiatan tersebut dengan mempertimbangkan tidak selamanya peserta KKP berada di lokasi tersebut, tindak lanjut dari kegiatan menjaga kebersihan lingkungan dilakukan dengan membuat jadwal rutin kegiatan gotong royong, kegiatan tersebut ditetapkan dengan sebelumnya melakukan koordinasi dengan kepala desa dan kepala dusun yang berada di desa kembang kerang, dengan tujuan untuk memastikan bahwa kegiatan bina lingkungan dengan kegiatan bersih-bersih bukanlah kegiatan KKP-DR semata, akan tetapi merupakan kegiatan rutin yang menjadi bagian dari program kerja desa atau dusun. Hal tersebut dilakukan agar setlah selsai pelaksanaan KKP DR Mahasiswa UIN Mataram, kegiatan tersebut harus tetap berjalan dibawah koordinasi kepala desa dan kepala dusun setmpat.

\section{Parktikal program}

Membangun kesadaran masyarakat akan pentingnya penerapan protocol kesehatan dalam melaksanakan aktivitas sehari-hari tentulah bukan sesuatu yang mudah. Fakta yang ditemukan, dalam setiap kegiatan, sebagian anggota masyarakat merasa terhalangi dan terganggu jika berkegiatan dengan menerapkan protocol kesehatan, terutama dalam hal penggunaan masker dan jaga jarak. Menumbuhkan kesadaran seseorang tidak dapat dilakukan dengan edukasi dan penyebaran informasi semata. Akan tetapi perlu dilatih untuk terbiasa dalam kondisi dan situasi yang berbeda dari seblumnya. 
Mempertimbangkan hal tersebut, peserta KKP-DR UIN Mataram dalam melaksanakan kegiatannya selalu memperagakan dan menerapkan protocol kesehatan, dimana kegiatan yang dilakukan melibatkan anggota masyarakat sebagai peserta kegiatannya. Hal tersebut dilakukan agar kebiasaan yang dilakukan dapat diterapkan oleh peserta tersebut dan mengajak anggota asyarakat lain untuk melakukannya. Peragaan protocol kesehatan yang dilakukan untuk memberika gambaran, bahwa menerapkan protocol kesehatan dalam bertinteraksi bukanlah sesuatu yang sulit atau menghambat terlaksananya kegiatan dengan baik. Jika kesadaran tersebut sudah dapat dibentuk, diharapkan tidak ada lagi anggota masyarakat yang merasa berat atau tergagnggu dalam melaksanakan aktivitas atau kegiatannya sambil menerapkan protocol kesehatan.

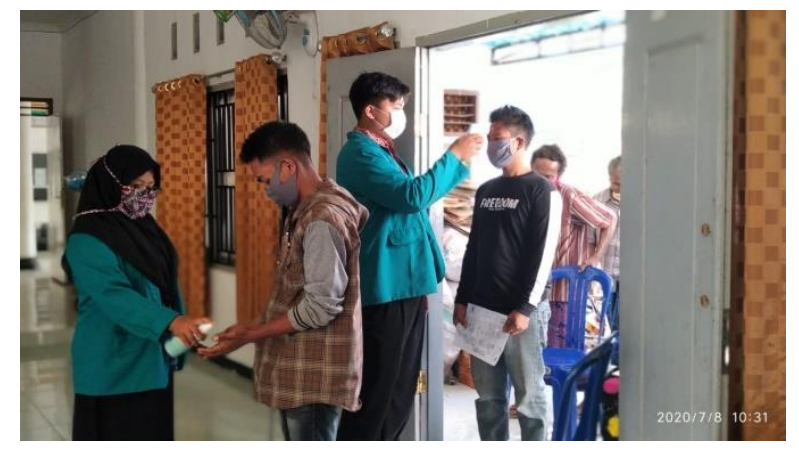

Gambar 3. Praktek Protokol Kesehatan (Penggunaan Masker, Cek Suhu Tubuh, dan Penggunaan Hand Sanitezer)

Kegiatan-kegiatan yang dilakukan di atas merupakan bentuk konstribusi UIN Mataram melalui kegiatan KKP-DR yang dilaksanakan oleh mahasiswa. Sampai kegiatan KKP-DR Selesai dilaksanakan pada tanggal 15 Agustus 2020 dan dilakukannya acara penarikan peserta KKP-DR. tidak ada laporan anggota masyarakat atau peserta KKP yang terpapar virus Covid-19. Hal tersebut menunjukkan bahwa meskipun masih terasa canggung dan belum terbiasa, penerapan protocol kesehatan covid 19 memberi dampak yang baik bagi anggota masyarakat Kembang Kerang. Kondisi tersebut diharapkan dapat dipertahankan selama status pandemic covid 19 masih diberlakukan oleh WHO dan dimasa-masa mendatang.

Menumbuhkan dan meningkatkan kesadaran masyarakat dalam hal apapun bukanlah hal yang mudah, apalagi terkait dengan merubah pola prilaku yang sudah dirasakan nyaman dan menjadi style dalam kehidupan sehari-hari. Konstribusi UIN Mataram melalui kegiatan KKP Mahasiswa dalam meningkatkan kesadaran masyarakat kembang kerang untuk menerapkan protocol kesehatan covid 19 tentu belum memberi pengaruh yang sangat signifikan bagi anggota masyarakat kembang kerang yang terdiri darii 3 dusun dengan luas wilayah menurut penggunaan yaitu 364,05 ha/m2.

Usaha yang berkesinambungan juga perlu dilakukan oleh pemerintah desa dan unsur lainnya, mengingat masyarakat desa kembang kerang memiliki jumlah penduduk 7.249 jiwa yang terhimpun dalam 2.113 kepala keluarga yang tersebar di tiga dusun berbeda. Penduduk desa kembang kerang sebagian besar petani dan buruh tani yang menggantungkan harapan perekonomiannya pada hasil bumi perkebunan dan persawahan meskipun ada beberapa yang 
merupakan pegawai negeri dan profesi lainnya. Kondisi tersebut akan menjadi tantangan tersendiri, karena anggota masyarakat kembang kerang harus selalu berinteraksi dengan satu sama lain, kemudian akibat dari jenis pekerjaannya, anggota masyarakat tidak semua dengan mudah dapat ditemui dirumahnya untuk diberikan penjelsan dan pemahaman akan pentingnya penerapan protokol kesehatan dalam kehidupan sehari-hari. Dimana, mayoritas anggota masyarakat yang sebagai petani akan keluar dari rumah pada pagi hari dan pulang pada sore hari bahkan malam. Untuk itu, diperlukan langkah-langkah yang lebih efektif selain yang sudah dilaksanakan oleh peserta KKP-DR mahasiswa UIN Mataram, agar masyarakat kembang kerang selalu dalam kondisi sehat dan tidak ada yang terpapar covid 19.

\section{Kesimpulan}

Pelaksanaan KKP-DR UIN Mataram sejak tanggal 2 Juli-15 agustus 2020 memberikan konstribusi positif terhadap peningkatan kesadaran masyarakat akan pentingnya penerapan protocol kesahatan covid 19. Di desa kemabnag kerang KKP DR dilaksnakan oleh anggota kelompok 22. Selama kegiatan berlangsung, program yang sudah dilaksanakan berkaitan dengan tujuan membantu pemerintah mengurangi dampak dari penyebaran virus covid 19 dalam bentuk kegiatan edukasi, bina lingkungan, dan praktekal program. Edukasi dilakukan untuk memberikan pemahaman tentang apa dan bagaimana protocol kesehatan diterapkan, bina lingkungan dilakukan dengan menggerakkan kembali kegiatan kebersihan lengkungan dan ditindaklanjuti dengan penyusunan jadwal kegiatan bersih-bersih yang berkelanjutan, dan yang ketiga adalah peragaan protocol kesehatan yang selalu ditunjukkan pada setiap pelaksanaan program KKP-DR yang melibatkan anggota masyarakat sebagai peserta.

Kegiatan-kegiatan yang dilaksanakan oleh peserta KKP-DR kaitannya dengan peningkatan kesadaran masyarakat tentang penerapan protocol kesehatan didukung oleh kepala desa, kepala dusun, serta aparat keamanan. Hal tersebut ditunjukkan dengan konstribusi aktif mereka dalam mendampingi dan memastika kegiatan yang dilakukan oleh mahasiswa terlaksana dengan baik dan nyampai ke masyarakat. Pengaruh dari kegiatan tersebut, sampai kegiatan KKP-DR Mahasiswa UIN Mataram 2020 selsai, tidak ada anggota masyarakat yang teridentifikasi terpapar virus corona atau covid 19. Meskipun kondisi tersebut tercapai tidak hanya pengaruh yang diberikan oleh kegiatan KKP-DR UIN Mataram, akan tetapi adanya factor lain yang dilakukan oleh tokoh masyarakat, tokoh agama, dan pemerintah daerah setempat. Diharapkan selama pandemic covid 19 ini masih berlaku dan di masa-masa mendatang kesadaran anggota masyarakat kembang kerang akan penting protocol kesehatan dalam melaksanakan aktivitas atau kegiatan sehari-hari selalu di praktekan dan anggota masyarakat menjadi terhindar dari paparan virus covid 19 atau penyakit lainnya.

\section{Ucapan Terima Kasih}

Penulis mengucapkan terima kasih kepada kepala LP2M UIN Mataram atas terselnggaranya kegiatan KKP-DR 2020 dengan baik dan lancar. Serta seluruh stockeholder masayrakat desa kembang kerang yang telah dengan aktif membantu dan memastika kegiatan mahasisswa UIN 
Mataram yang sedang melakukan kegiatan pengabdian terlaksana sesuai dengan rencana dan dampaknya dirasakan langsung oleh masyarakat, dan terakhir kepada team KKP-DR UIN Mataram yang telah mengidentifikasi seluruh masalah dan informasi tentang penyebaran covid 19 di lokasi KKP serta kegiatan-kegiatan yang sudah dilaksanakan dipastikan terlaksana dengan lancar, sehingga dalam penyusun artikel ini tersedia informasi yang valid dan konprehnsif tentang konstribusi UIN mataram dalam meningkatkan kesadaran masayarakat kembang kerang mematuhi protocol covid 19.

\section{Daftar Pustaka}

Achmanto Mendatu, Pemulihan Trauma: Strategi Penyembuhan Trauma Untuk Diri Sendiri, Anak, dan Orang Lain di Sekitar Anda, (Yogyakarta: Panduan, 2010).

Atosokhi Gea. Dkk. (2002). Relasi dengan diri sendiri. Elek Media Komputindo

Clifton D. Bryant, Dennis L. Peck (2006). 21st Century Sociology: A Reference Handbook. Sage Phublication

Carter, N. 1992. Disaster Management: A Disasters Manager Handbook. Asian Development Bank. Manila - Philippines.

Dessler, Gary. (1997). Manajemen Sumberdaya Manusia. Jakarta : PT. Prenhallindo.

LP2M (2020). Pedoman Pelaksanaan KKP DR 2020. Universitas Islam Negeri Mataram

Mathis.L.Robert dan Jackson.H.John. 2001, Manajemen Sumber Daya Manusia, Jakarta :

Mead, G. H. (1999). Mind, Self, and Society. Chicago: University of Chicago Press.

Undang Undang RI. (2012). Pendidikan Tinggi No 12. Fungsi dan Tujuan Perguruan Tinggi

World Healt Organitation. (2021). Coronavirus disease (COVID-19) pandemic. Retrieved November 30 Maret $2021 \quad$ https://www.who.int/emergencies/diseases/novel-coronavirus2019?gclid=EAIaIQobChMI9crX4ffp7wIVUCsrChOSsAggEAAYASAAEgLil D BwE 